\section{Carbohydrate-binding protein from Polysphondylium pallidum implicated in intercellular adhesion}

INTERCELLULAR adhesion is generally believed to be mediated by specific macromolecular components on the surface of the interacting cells. Soluble factors which may play a part in this process have been identified in a number of system $\mathrm{s}^{1-8}$. We have already described a developmentally-regulated ${ }^{9}$ carbohydrate binding protein ${ }^{10,11}$ from the cellular slime mould Dictyostelium discoideum that appears in differentiating amoebae in close correlation with the development of cohesiveness ${ }^{10}$. This protein is assayed by its erythrocyte agglutination activity that can be inhibited by specific sugars. We now report the isolation of a similar protein from another cellular slime mould, Polysphondylium pallidum that seems to mediate specific cellular adhesion as judged from the following findings: (1) it is present on the cell surface; (2) it is present when the cells are differentiated to a cohesive state but absent when the cells are not cohesive; (3) addition of the purified protein promotes cell cohesion; (4) sugars which react with the active site of the molecule block cell cohesion produced either by the added purified substance or by the endogenous substance present on cohesive cells; (5) the precise reactivities of the protein from $P$. pallidum differ from the protein from $D$. discoideum, which correlates with the segregation of these cells in mixed culture.

$P$. pallidum, like the other cellular slime moulds, exhibits two distinct phases in its life cycle ${ }^{12-14}:$ a non-social vegetative phase and a cohesive phase, initiated by starvation. To generate vegetative and cohesive cells, $10^{5}$ spores of $P$. pallidum WS-320 in association with pregrown Aerobacter aerogenes were inoculated on to standard medium (SM) agar plates ${ }^{15}(100 \mathrm{~mm}$ diameter) and incubated in a moist atmosphere at $22^{\circ} \mathrm{C}$ in the dark. Cells in the growth phase (or not far from it) were collected from plates after $63 \mathrm{~h}$ of incubation when their density was fairly low $\left(7 \times 10^{7}\right.$ per plate), washed in cold $\mathrm{H}_{2} \mathrm{O}$ and separated from bacteria by centrifugation. The amoebae were differentiated ${ }^{16}$ into the aggregation-competent state by suspension $\left(10^{7} \mathrm{ml}^{-1}\right)$ and reciprocal shaking in $0.0167 \mathrm{M}$ $\mathrm{Na}_{2} \mathrm{HPO}_{4}-\mathrm{KH}_{2} \mathrm{PO}_{4}, p \mathrm{H6}$.0. At intervals cells were removed for assay of cohesiveness and to be extracted for erythrocyte agglutination activity (Fig. 1). The cohesiveness assay, modified from one described previously ${ }^{10}$, measures the size of clumps formed from single cells passively brought into contact by roller-tube agitation. It has been demonstrated ${ }^{20,21}$ for $D$. discoideum that the size of free suspension agglutinates formed from single cells in the presence of EDTA correlates with the ability of the cells to form morphogenic contacts.

Table 1 Sugar effects on agglutination of erythrocytes by discoidin or $P$. pallidum agglutinin

Sugar

Sugar concentration for $50 \%$ inhibition of agglutination $(\mathrm{mM})$

Lactose

$\alpha$ Methyl-D-galactose

$P$. pallidum agglutinin $D$. discoideum

D-Galactose

$\mathrm{N}$-acetyl-D-galactosamine

D-Fucose

L-Fucose

3-O-methyl-D-glucose

$\alpha$ Methyl-D-glucose

$\beta$ Methyl-D-glucose

D-Glucose

D-Glucosamine

$\mathrm{N}$-acetyl-D-glucosamine

D-Mannose

$\alpha$ Methyl-D-mannose

1.6
6.2
6.2
25
25
50
100
$\geq 100$
$\geq 100$
$\geq 100$
$\geq 100$
$\geq 100$
$\geq 100$
$\geq 100$

1.6

6.2

6.2

25

50
100

$\geq 100$

$\geq 100$

$\geq 100$

$\geq 100$

$\geq 100$

12.5
6.2
25
1.6
3.1
12.5
1.6
12.5
100
$\geq 100$
$\geq 100$
$\geq 100$
$\geq 100$
$\geq 100$

Purified $P$. pallidum agglutinin and discoidin ${ }^{11}$ were assayed for agglutination activity as described in Fig. 1 in the presence of a series of concentrations of sugars to determine the sugar concentration required to inhibit agglutination activity by $50 \%$.

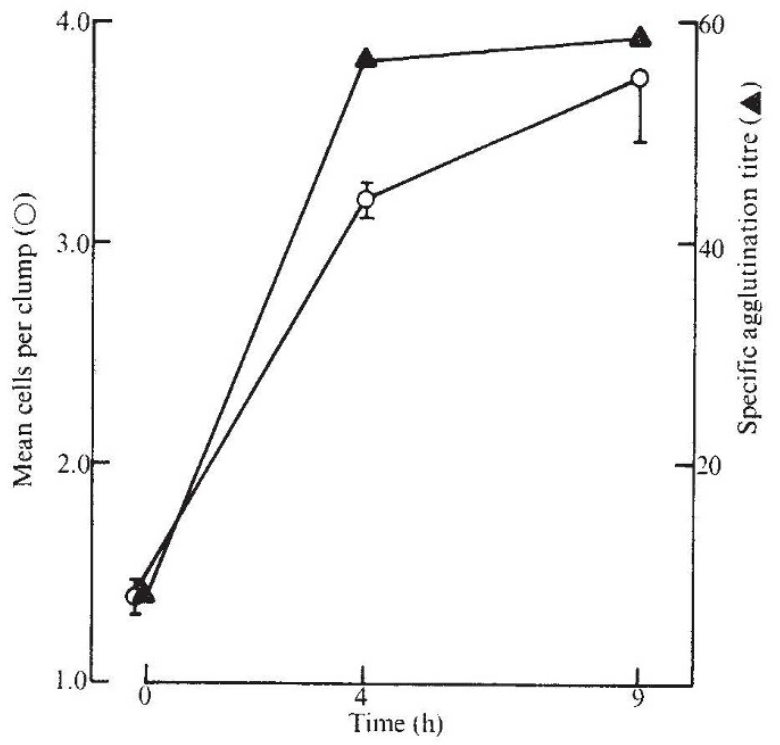

Fig. 1 Agglutinin activity $(\boldsymbol{\Delta})$ and cohesiveness $(0)$ during development of $P$. pallidum in suspension culture. Cells maintained on SM plates ${ }^{15}$ with bacteria for $63 \mathrm{~h}$ were washed free of bacteria and inoculated in suspension medium without bacteria ${ }^{16}$. Aliquots of differentiating cells were removed for assay at the times indicated. For the agglutination activity assay extracts were prepared by sonicating $3 \times 10^{8}$ cells (Bronwill Sonifer with needle probe; four bursts of $25 \mathrm{~s}$ each at intensity 50 ) in $3 \mathrm{ml}$ of $75 \mathrm{mM} \mathrm{NaCl}, 75 \mathrm{mM} \mathrm{KCl}, 1 \mathrm{mM}$ EDTA, $15 \mathrm{mM}$ Tris- $\mathrm{HCl}(p \mathrm{H} \mathrm{7.3})^{17}$ containing $0.3 \mathrm{M}$ D-galactose. Extracts were centrifuged at $150,000 \mathrm{~g}$ for $45 \mathrm{~min}\left(4^{\circ} \mathrm{C}\right)$. Supernatants, after extensive dialysis against $75 \mathrm{mM} \mathrm{NaCl}, 75 \mathrm{mM} \mathrm{Na}{ }_{2} \mathrm{HPO}_{4}-$ $\mathrm{KH}_{2} \mathrm{PO}_{4}(p \mathrm{H}$ 7.2) (PBS) were assayed with formalinised human red blood cells ${ }^{18}$ (FHRBC). Assays were performed in Microtiter $\checkmark$ plates (Cooke Engineering) using serial twofold dilutions of the extract. Each well contained $25 \mu \mathrm{l}$ of saline $(0.15 \mathrm{M} \mathrm{NaCl})$ plus $25 \mu \mathrm{l}$ of extract diluted in PBS to which $25 \mu \mathrm{l}$ of a $2.5 \%(\mathrm{v} / \mathrm{v})$ suspension of FHRBC in PBS was added. The patterns were read after $1.5 \mathrm{~h}$. Titre was expressed as the reciprocal of the highest dilution giving positive agglutination. Specific agglutination activity was expressed as titre divided by protein concentration. Protein concentration was determined by the method of Lowry et al..$^{19}$ with bovine serum albumin as a standard. For the cohesiveness assay the procedure was as follows: (1) Cells collected from the suspension culture were washed in water $\left(4^{\circ} \mathrm{C}\right)$ and suspended in EDTA-phosphate buffer $(16.7 \mathrm{mM}$ $\mathrm{Na}_{2} \mathrm{HPO}_{4}-\mathrm{KH}_{2} \mathrm{PO}_{4}, 10 \mathrm{mM}$ EDTA $(p \mathrm{H} \mathrm{6.2})$ ) as modified from Gerisch $^{20}$. (2) The suspension was dispersed into single cells by repeated pipetting through a fine-tipped pipette and was adjusted to a concentration of $5 \times 10^{5}$ cells $\mathrm{ml}^{-1} .1 \mathrm{ml}$ of this suspension was diluted 50-fold in EDTA-phosphate buffer and counted with Coulter counter (Model ZB-I) using a $200 \mu \mathrm{m}$ aperture with $1 /$ aperture current at $1 / 16,1 /$ amplitude at $1 / 8$ and the lower and upper thresholds set at 20 and $\infty$. (3) $5 \mathrm{ml}$ of the cell suspension was added to a $17 \times 150 \mathrm{~mm}$ glass test tube. The tube was rolled about its long axis at $20 \mathrm{r.p} . \mathrm{m}$. for $30 \mathrm{~min}\left(23^{\circ} \mathrm{C}\right)$. (4) The contents of the tube were diluted 20-fold in EDTA-phosphate buffer and counted in the Coulter counter at the above settings. With coincidence corrections, the ratio of the total number of particles before and after rolling was computed. This ratio is the mean number of cells per clump and is taken as an index of cell cohesiveness. The standard error of the mean for three separate determinations is shown.

Cohesiveness of cells and specific agglutination activity in cell extracts increased in parallel after separation from bacteria (Fig. 1). In subsequent experiments, we found that synchronous growth-phase cells grown in suspension with bacteria ${ }^{16}$ under conditions in which all cells had equal and ample bacterial food, contained no detectable agglutination activity. Thus agglutination activity was absent in vegetative cells, but appeared in food-deprived, differentiating cells.

To purify agglutinin we cultured cells on SM plates for $90 \mathrm{~h}$ in the dark. Under these conditions the cells become cohesive but do not develop beyond broad, loose aggregates. We sonicated the cells in $0.15 \mathrm{M} \mathrm{NaCl}, 0.3 \mathrm{M}$ galactose, adsorbed the dialysed supernatant with formalinised erythrocytes and (Continued on page 149) 
(Continued from page 128)

eluted the agglutinin with D-galactose (ref. 22 and details to be published). Based on specific agglutination titre a 75 -fold purification with $50 \%$ recovery was achieved. Since the product was pure by electrophoretic criteria (Fig. 2) this result indicates that the agglutinin constitutes approximately $1 \%$ of the total extractable protein in cohesive $P$. pallidum cells. The subunit molecular weight of the $P$. pallidum protein is estimated to be about 25,000 (Fig. 2) as compared with 26,000 for discoidin ${ }^{11}$; its isoelectric point is 7.0 (details to be published) whereas the value is 6.1 for discoidin ${ }^{11}$. The two agglutinins also differed in their interaction with a wide range of sugars (Table 1). For discoidin, the most potent inhibitors were $\mathrm{N}$-acetyl-D-galactosamine and 3-O-methyl D-glucose. In contrast, the $P$. pallidum agglutinin required 15 times as much of the former and 60 times as much of the latter for comparable inhibition but was eight times more sensitive to lactose and four times more sensitive to D-galactose.

Since the protein agglutinated erythrocytes we determined if it also agglutinated $P$. pallidum cells. To test this we added the pure protein to cohesive $P$. pallidum cells which had been

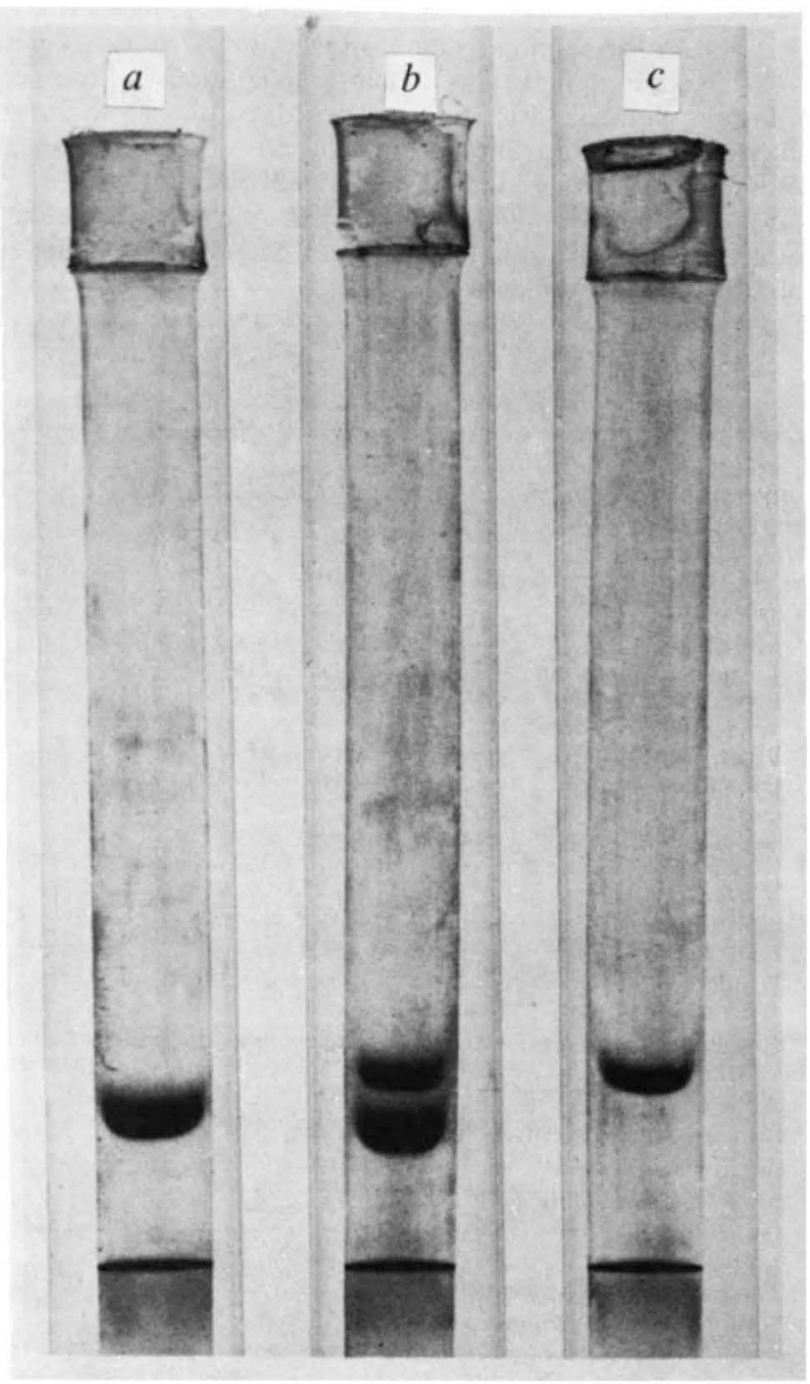

Fig. 2 Polyacrylamide gel electrophoresis of purified agglutinins from $P$. pallidum and $D$. discoideum. Approximately $25 \mu \mathrm{g}$ of each protein was applied to a discontinuous sodium dodecyl sulphate (SDS)-polyacrylamide system ${ }^{23}$ with a $3 \%$ acrylamide stacking gel and an $8.0 \%$ separating gel as described previously ${ }^{11}$. To assure complete solubilisation, samples were heated at $100^{\circ} \mathrm{C}$ for $5 \mathrm{~min}$ immediately before application to gels. Cytochrome $c(5 \mu \mathrm{g})$ was added routinely to samples as a reference protein. The discoidin preparation and molecular weight calibration were as described previously ${ }^{11}$. $a, P$. pallidum; $b$, mixture; $c, D$. discoideum.

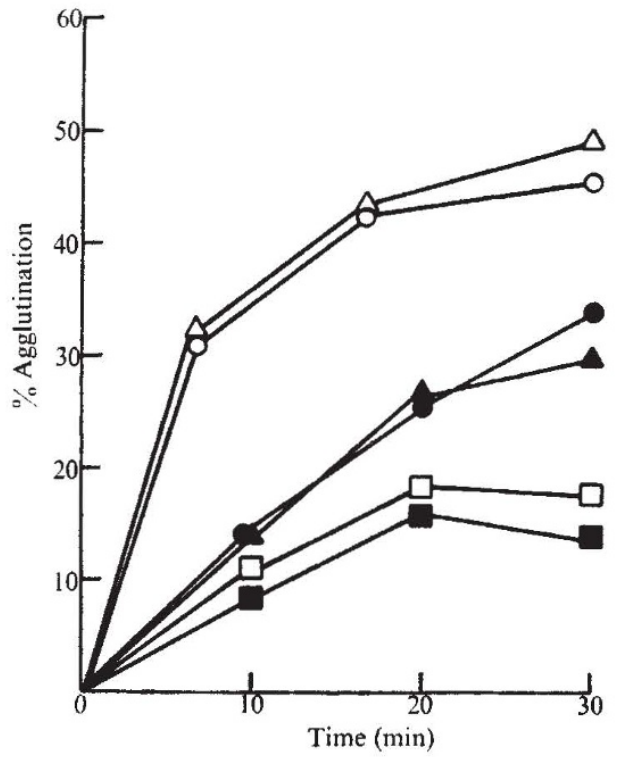

Fig. 3 Agglutination of heat-treated $\left(60^{\circ} \mathrm{C}\right) P$. pallidum cells by purified agglutinin. Cells were collected from 90 -h plates, washed and suspended, $10^{7} \mathrm{ml}^{-1}$, in $16.7 \mathrm{mM} \mathrm{Na} \mathrm{HPO}_{4}-\mathrm{KH}_{2} \mathrm{PO}_{4}$ $\left(p \mathrm{H}\right.$ 6.0) buffer, and heated at $60^{\circ} \mathrm{C}$ for $10 \mathrm{~min}$. Agglutinin was purified and then extensively dialysed against PBS. Since there was partial loss of activity, the concentration of active agglutinin was estimated on the basis of agglutination activity. Agglutination assays were done in plastic trays with $16 \mathrm{~mm}$ wells (Linbro FB-54). Each well held a total of $0.5 \mathrm{ml}$ consisting of $2 \times 10^{6}$ cells $\mathrm{ml}^{-1}$ plus one of the following sets of constituents: $(\boldsymbol{\Delta})$ PBS; $(\triangle)$ purified agglutinin $\left(0.5 \mu \mathrm{g} \mathrm{ml}^{-1}\right)$; $(\square)$ purified agglutinin $\left(0.5 \mu \mathrm{g} \mathrm{ml}^{-1}\right)+\mathrm{D}$-galactose $(0.2 \mathrm{M}) ;(\mathrm{O})$ purified agglutinin $\left(0.5 \mu \mathrm{g} \mathrm{ml}^{-1}\right)+\mathrm{D}$-glucose $(0.2 \mathrm{M})$; (1) $0.2 \mathrm{M}$ galactose; (0) $0.2 \mathrm{M}$ D-glucose. A separate well was used for each time point. The tray was gyrated at 115 r.p.m. on a New Brunswick G-24 shaker $\left(23^{\circ} \mathrm{C}\right)$. At $10 \mathrm{~min}$ intervals the contents of wells were carefully removed, diluted in $20 \mathrm{ml}$ of saline and single cells were counted with a Coulter counter $(100 \mu \mathrm{m}$ aperture; 1 /aperture current $=1 / 4 ; 1 /$ amplitude $=2 ;$ threshold $=20-80$ ) . The percentage agglutination was expressed as the percentage of single cells that had disappeared relative to time 0 (ref. 24).

heated at $60^{\circ} \mathrm{C}$ for $10 \mathrm{~min}$ to reduce their endogenous agglutination (Fig. 3). Agglutination was assayed by measuring the disappearance of single cells in a gyrated suspension ${ }^{24,25}$. The purified protein $\left(0.5 \mu \mathrm{g} \mathrm{ml}^{-1}\right)$ agglutinated the $P$. pallidum cells; and this agglutination was blocked by $0.2 \mathrm{M}$ D-galactose, but not by $0.2 \mathrm{M}$ D-glucose (Fig. 3).

We next looked for agglutinin on the surface of cohesive cells. When erythrocytes and cohesive $P$. pallidum cells were mixed and shaken on a slide, large mixed clumps formed within a minute, consisting of slime mould cells in contact with one another and with erythrocytes. D-Galactose $(0.15 \mathrm{M})$ blocked formation of these clumps whereas D-glucose did not. To test the possibility that erythrocytes were being agglutinated because of secretion or release of protein from the slime mould cells, we maintained cells in medium for $10 \mathrm{~min}$, then spun them out, and tested the supernatant for erythrocyte agglutination activity. Since no agglutination was observed, this suggested that the agglutinin is not secreted and is therefore present on the surface of the slime mould cells.

In view of this finding we investigated whether the saccharides that interact with this protein blocked the endogenous cohesiveness of the slime mould cells. In a previous experiment (Fig. 3) we found that cells heated to $60^{\circ} \mathrm{C}$ for $10 \mathrm{~min}$ retained some cohesiveness. With a milder heat treatment $\left(51^{\circ} \mathrm{C}\right.$ for $\left.10 \mathrm{~min}\right)$ the cells were significantly more cohesive. (It should be noted that purified factor retained about $50 \%$ of its erythrocyte agglutination activity when heated under these conditions.) Determining agglutination by measuring the disappearance of single cells, we examined the effects of several sugars on this residual cohesiveness. D-Galactose and lactose were effective 
inhibitors down to $6 \mathrm{mM}$ whereas D-glucose and D-mannose were effective only at $500 \mathrm{mM}$ (Fig. $4 a$ ). When living, untreated $P$. pallidum cells were used, differential sugar inhibition of cohesiveness was again observed (Fig. $4 b$ and $c$ ); but compared with the results with heat-treated cells, the concentrations of sugars required for differential inhibition were about 15 times higher. The difference between heat treated and living cells may be due to $(a)$ more functional agglutinin in living cells; (b) higher binding affinity between agglutinin and its receptor in living cells; or $(c)$ secondary adjunct binding sites in living cells.

Our findings support a role for the carbohydrate-binding protein in intercellular adhesion in $P$. pallidum, although its participation in other differentiative processes should be
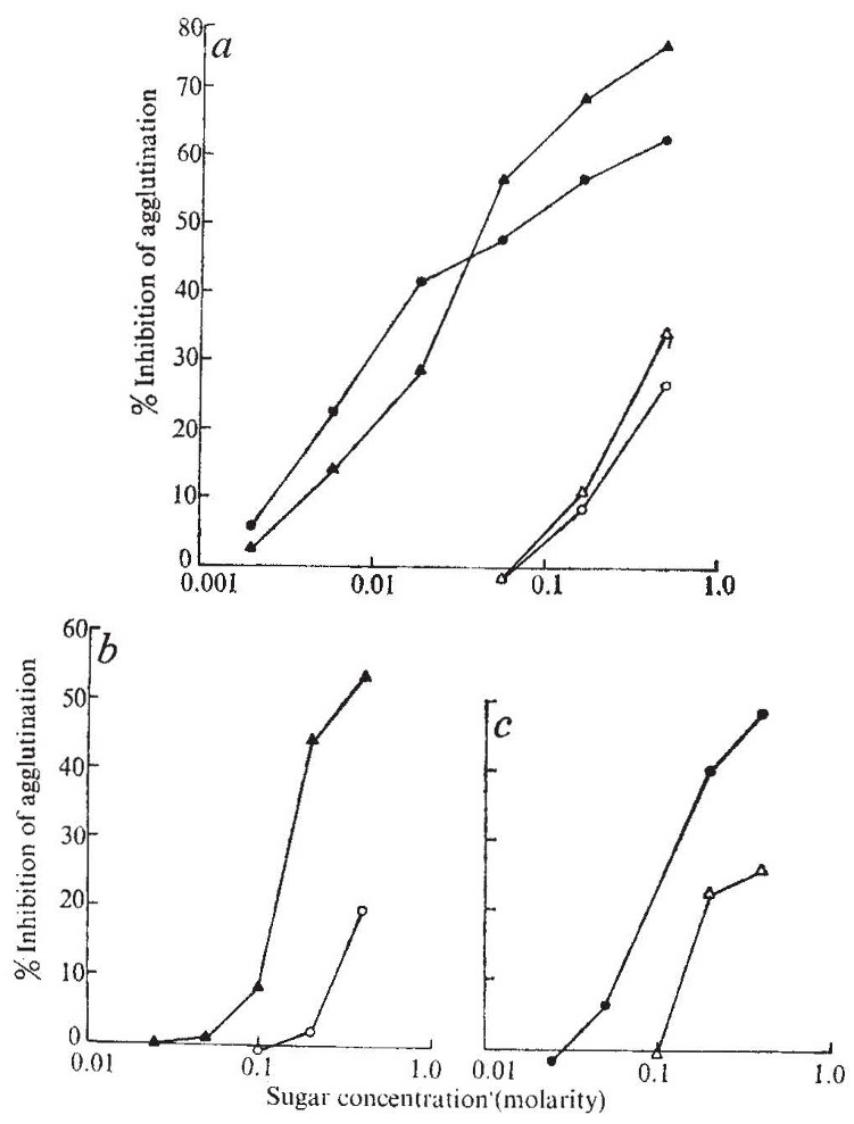

Fig. 4 Effect of sugars on agglutination of heat-treated $\left(51^{\circ} \mathrm{C}\right)$ (a) or normal (b, and c) $P$. pallidum cells. $a$, Cells from $90 \mathrm{~h}$ plates were suspended at $10^{7} \mathrm{ml}^{-1}$ in $16.7 \mathrm{mM} \mathrm{Na} \mathrm{HPO}_{4}-\mathrm{KH}_{2} \mathrm{PO}_{4}$ $p \mathrm{H} 6.0$, buffer and heated at $51^{\circ} \mathrm{C}$ for $10 \mathrm{~min}$. The cells were then washed and dispersed in the same buffer. Each well of the Linbro tray contained $2 \times 10^{6}$ cells $\mathrm{ml}^{-1}$ plus PBS buffer containing the indicated concentration of sugar $(0.5 \mathrm{ml}$ total volume $)$. There were three replicate wells for each treatment. The plate was gyrated at 115 r.p.m. for $60 \mathrm{~min}$, by which time agglutination had reached a plateau. The contents of each well were diluted and counted as in Fig. 3 to determine the percentage reduction in agglutination relative to controls containing no sugar. The selective inhibition of agglutination seen quantitatively in the figure was verified qualitatively by visual inspection $(b$ and $c$ ) Cells were collected from $93-96 \mathrm{~h}$ plates. The cells were suspended and dispersed into EDTA-phosphate buffer (Fig. 1 legend) Each well of the Linbro tray contained $3 \times 10^{6}$ cells $\mathrm{ml}^{-1}$ plus EDTA-phosphate buffer or sugar in EDTA-phosphate buffer at different concentration $(0.5 \mathrm{ml}$ total volume). Galactose $(\boldsymbol{\Lambda})$ and mannose $(0)$ were compared in one experiment $(b)$ and lactose $(0)$ and glucose $(\triangle)$ in the other $(c)$. There were three replicate wells for each treatment. The tray was gyrated at 115 r.p.m. for $60 \mathrm{~min}$, a period sufficient to attain equilibrium. The contents of each well were diluted into $20 \mathrm{ml}$ of EDTAphosphate buffer and single cells were counted $(100 \mu \mathrm{m}$ aperture; 1 /aperture current $=0.354,1 \mathrm{~A}=1$, thresholds $=10-60$ ). As above, the percentage reduction in agglutination was determined for each sugar. The selective sugar effects were verified visually. considered. Our working hypothesis is that this protein is a cell-ligand $^{26}$ that binds slime mould amoebae together by attaching to carbohydrate-containing receptors on adjacent cells. The basis of the erythrocyte agglutination assay would derive from a structural resemblance between the erythrocyte surface oligosaccharides and the native slime mould receptor. Thus, under this model, there would be two principal components in the adhesion system: a multivalent carbohydratebinding protein which is a peripheral membrane protein ${ }^{27}$ and a carbohydrate receptor possibly associated with an integral membrane component ${ }^{27}$. Carbohydrate-containing macromolecules have been implicated in cell adhesion in several other systems, including microbe-host cell interactions ${ }^{18-30}$, mating reactions of bacteria ${ }^{31}$, yeast ${ }^{32}$ and Chlamydomonas ${ }^{33}$ and cell-cell interactions in tissue formation ${ }^{3,34-36}$.

Finally, we suggest that the difference in the carbohydratebinding specificities of the agglutinins from $D$. discoideum and $P$. pallidum may underlie the selective intercellular affinities exhibited by cells of these species ${ }^{37-39}$. Further work is required to test our model for slime moulds and to determine its relevance in the analysis of specific cellular interactions in higher systems.

We thank Dr Danton O'Day for $P$. pallidum WS-320, John Kafka for helping to develop the cohesiveness assay and R. W. Reitherman for his aid and suggestions in the sugar inhibition studies. S.D.R. is a postdoctoral fellow of the American Cancer Society. D.L.S. is a postdoctoral fellow and J.E.R. is a graduate student supported by a grant from the Alfred P. Sloan Foundation. This research was supported by grants from the National Institute of Mental Health and the Alfred P. Sloan Foundation.

\section{STEVen D. Rosen \\ DAVID L. SIMPSON \\ JED. E. ROSE}

SAMUel H. BARONDES

Department of Psychiatry,

University of California, San Diego School of Medicine, La Jolla, California 92037

Received June 24; revised August 23, 1974.

${ }^{1}$ Humphreys, T., Devl Biol., 8, 27 (1963).

2 Moscona, A. A., Proc, natn. Acad. Sci. U.S.A., 49, 742 (1963).

3 Turner, R., and Burger, M. M., Nature, 244, 509 (1973).

${ }^{4}$ Brock, T. D., Proc. natn. Acad. Sci. U.S.A., 54, 1104 (1965).

${ }^{5}$ Wiese, L., J. Phycol., 1, 46 (1965).

${ }^{6}$ Lilien, J., and Moscona, A. A., Science, 157, 70 (1967).

7 Oppenheimer, S. B., and Humphreys, T., Nature, 232, 125 (1971).

${ }^{8}$ Garber, B. B., and Moscona, A. A., Devl Biol., 27, 235 (1972).

9 Rosen, S. D., thesis. Cornell Univ. (1972).

10 Rosen, S. D., Kafka, J. A., Simpson, D. L., and Barondes, S. H., Proc. natn. Acad. Sci. U.S.A., 70, 2554 (1973).

${ }^{11}$ Simpson, D. L., Rosen, S. D., and Barondes, S. H., Biochemistry (in the press).

12 Bonner, J. T., The cellular slime molds, second ed. (Princeton University Press, 1967).

${ }^{13}$ Gerisch, G., in Current topics in developmental biology (edit. by Moscona, A. A., and Monroy, A.), 3, 157 (Academic Press, New York, 1968).

14 Bonner, J. T., Ann. Rev. Microbiol., 25, 75 (1971).

15 Sussman, M., in Methods of cell physiology (edit. by Prescott, O.), 2, 297 (Academic Press, New York, 1966).

${ }^{16}$ Gerisch, G., Wilhelm Roux Arch. Entwicklungsmech., 152, 632 (1960).

17 Takeuchi, I., and Yabuno, K., Expl Cell Res., 61, 183 (1970).

18 Butler, W. T., J. Immun., 90, 663 (1963).

${ }^{19}$ Lowry, O. H., Rosebrough, N. J., Farr, A. L., and Randall, R. J., J. biol. Chem., 193, 265 (1951).

${ }^{20}$ Gerisch, G., Expl Cell. Res., 25, 535 (1961).

${ }^{21}$ Beug, H., Katz, F. E., and Gerisch, G., J. Cell Biol., 56, 647 (1973).

22 Reitherman, R. W., Rosen, S. D., and Barondes, S. H., Nature, 248, 599 (1974)

${ }^{23}$ Laemli, U. K., Nature, 227, 680 (1970).

${ }^{24}$ Oppenheimer, S. B., and Odencrantz, J., Expl Cell. Res., 73, 475 (1972).

25 Orr, C. W., and Roseman, S., J. Membrane Biol., 1, 109 (1969).

${ }^{26}$ Moscona, A. A., Devl Biol., 18, 250 (1968).

${ }^{27}$ Singer, S. J., and Nicolson, G. L., Science, 175, 720 (1972). 
28 Burnet, F. M., Physiol. Rev., 31, 131 (1951)

29 Neter, E., Bact. Rev., 20, 166 (1956).

30 Winzler, R. J., Int. Rev. Cytol., 29, 77 (1970)

31 Sneath, P. H. A., and Lederberg, J., Proc. natn. Acad. Sci. U.S.A., 47, 86 (1961).

32 Crandall, M. A., and Brock, T. D., Science, 161, 473 (1968).

${ }^{33}$ Weise, L., and Shoemaker, D. W., Biol. Bull., 138, 88 (1970).

34 Moscona, A. A., J. cell. comp. Physiol. Suppl., 160, 65 (1962).

35 Oppenheimer, S. B., Edidin, M., Orr, C. W., and Roseman, S., Proc. natn. Acad. Sci. U.S.A., 63, 1395 (1969).

${ }^{36}$ Barondes, S. H., in The neurosciences second study program (edit. by Schmitt, F. O.), 747 (Rockefeller University Press, New York, 1970).

37 Raper, K. B., and Thom, C., Am. J. Bot., 28, 69 (1941).

38 Shaffer, B. M., Q. Jl Microsc. Sci., 98, 377 (1957).

39 Bonner, J. T., and Adams, M. S., J. Embryol. exp. Morphol., 6, 346 (1958)

\section{Cyclic expression of a growth conditioning factor (MGF) on the cell surface}

THE cell surface has been implicated as a regulation site for cell division in various systems. Enzymatic alteration of the cell surface can initiate DNA synthesis in contact inhibited cells ${ }^{1-3}$ and changes in membrane components have been correlated with the expression of the transformed phenotype $\mathrm{e}^{4-10}$ and with the entry into the $\mathrm{S}$ phase of normal cells ${ }^{11}$. We describe here a system in which the induction into DNA synthesis of a nondividing cell population is regulated by a factor exteriorised only during the $\mathrm{S}$ and mitosis periods at the surface of the producer cells.

Peritoneal macrophages can be maintained in vitro but do not proliferate; they can, however, be induced to synthesise DNA and divide in medium conditioned by cells of the same species ${ }^{12-14}$. In our system medium conditioned by $\mathbf{L}$ cells in logarithmic growth was used and tested on macrophages collected from the peritoneal cavities of starch-inoculated $\mathrm{C} 57 \mathrm{BL} / 6 \mathrm{~J}$ mice as described previously ${ }^{13}$. The assays were performed in Lab-Tek four chamber slides seeded with $3.0 \times 10^{5}$ nucleated peritoneal cells per chamber. Thirty minutes after seeding, the cultures were washed twice with phosphate buffered saline (PBS) to remove unattached cells, and refed. After 2-3 d the desired concentration of samples was diluted in TES-HEPES-buffered Eagle's medium, pH 7.6 (ref. 15), with $10 \%$ foetal calf serum (FCS) and added to macrophages in the presence of $0.2 \mu \mathrm{Ci} \mathrm{ml}{ }^{-1}{ }^{3} \mathrm{H}$-thymidine (dT) (specific activity, $52 \mathrm{Ci} \mathrm{mmol}^{-1}$ ). After $5 \mathrm{~d}$ the cells were fixed with Carnoy's solution and prepared for autoradiography.

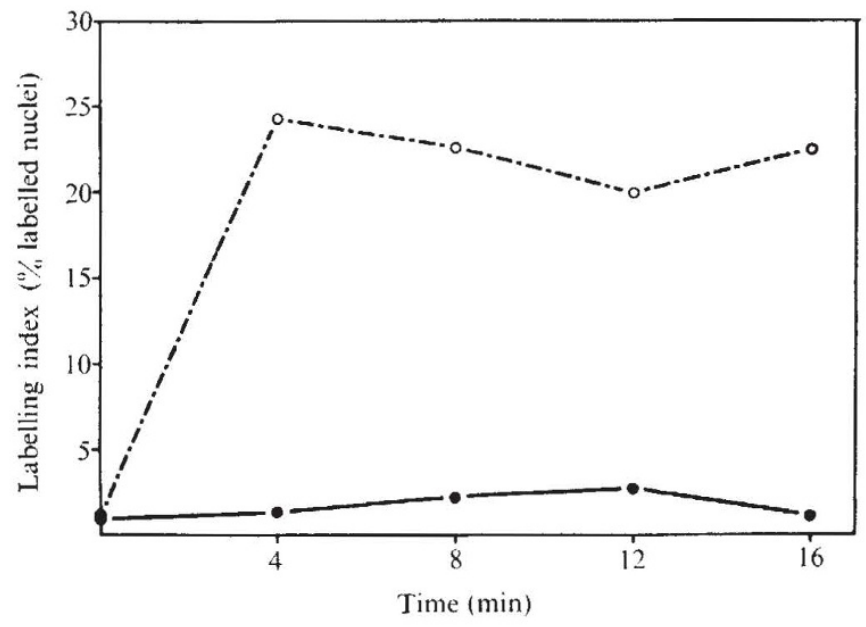

Fig. 1 Release of MGF with increasing time of trypsin treatment. Incubation of $2 \mathrm{ml}$ of $0.1 \%$ trypsin $\left(\mathrm{O}_{-\infty}\right)$ or medium alone (-) with duplicate milk dilution bottles of $\mathrm{L}$ cells previously washed twice with PBS. Reaction stopped with $10 \%$ FCS. All samples assayed in duplicate at a trypsin digest concentration of $40 \%$. Assay was for $5 \mathrm{~d}$ with a continuous label of $0.2 \mu \mathrm{Ci} \mathrm{ml} \mathrm{m}^{-1} \mathrm{dT}$.

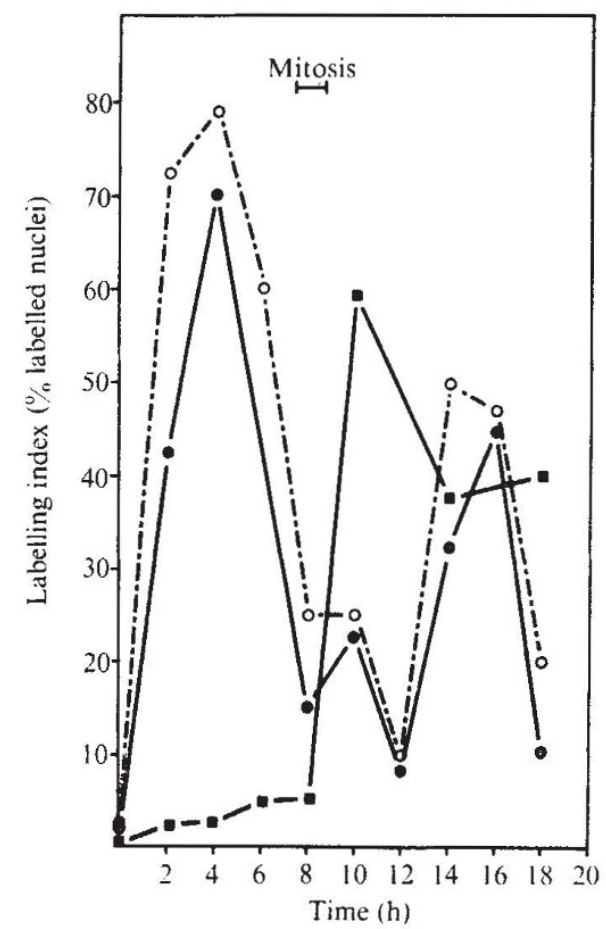

Fig. 2 Spontaneous and tryptic release of MGF from synchronised L cells. L cells seeded $24 \mathrm{~h}$ previously, $1 \times 10^{6}$ cells per $60 \mathrm{~mm}$ Petri dish were synchronised with $10^{-3} \mathrm{M}$ dT as described in the text. At different times after release, $\mathrm{L}$ cell coverslips were pulsed for $20 \mathrm{~min}$ with $2.0 \mu \mathrm{Ci} \mathrm{ml} \mathrm{m}^{-1} \mathrm{dT}$ (specific activity $52 \mathrm{Ci}$ $\mathrm{mmol}^{-1}$ ). Coverslips were fixed in Carnoy's solution for autoradiography. Cells were read for labelled nuclei $\left.\left(\bigcirc_{---}\right)\right)$. At the times indicated duplicate L cell cultures were trypsinised with $0.1 \%$ trypsin for $5 \mathrm{~min}$ and the reaction was stopped with $10 \%$ FCS. Samples of medium incubated with the cells from the time of release from the dT block were taken. Trypsin digests ( and conditioned medium ( $\square$ ) were assayed on macrophages at a concentration of $40 \%$ for $5 \mathrm{~d}$ with $0.2 \mu \mathrm{Ci} \mathrm{ml} \mathrm{m}^{-1} \mathrm{dT}$. Autoradiography was performed as described previously.

The presence of macrophage growth factor (MGF) not only in the conditioned medium, but also in cell lysates was demonstrated as follows. Suspensions of $4 \times 10^{6} \mathrm{~L}$ cells per $\mathrm{ml}$ were washed repeatedly and sonicated for $3 \mathrm{~min}$ at 30 -s intervals. Dilutions of whole sonicates were assayed on macrophages for stimulatory activity. An increase in the concentration of crude cell lysates increased the number of labelled macrophages. To determine whether stimulation was specific, two mouse cell lines which do not produce active conditioned medium were sonicated and tested for activity: neither showed stimulatory activity in their lysates (data not shown).

To determine the cellular localisation of the MGF, L cells were treated with $0.1 \%$ trypsin (Flow Laboratories) $24 \mathrm{~h}$ after plating at $37^{\circ} \mathrm{C}$ for periods of $0-16 \mathrm{~min}$; trypsinisation was terminated with $10 \%$ FCS or soybean trypsin inhibitor. Samples were filtered through $0.22 \mathrm{~nm}$ filters to eliminate contaminating L cells. As Fig. 1 shows, maximal activity was released at $4 \mathrm{~min}$; $0.05 \%$ purified trypsin (Worthington) released comparable amounts of activity (data not shown). No detectable MGF was released when cells were incubated with medium alone during the experimental period.

Since changes occur in the components of the cell surface during the cell cycle we investigated whether MGF was released by trypsin only during certain phases of the cycle. L cells were synchronised by a double dT block $\left(10^{-3} \mathrm{M}\right.$ dT for $16 \mathrm{~h} ; 6 \mathrm{~h}$ release, followed by another $16 \mathrm{~h}$ block). At $2 \mathrm{~h}$ after release, $70 \%$ of the cells were in the $\mathrm{S}$ phase as shown by autoradiography after a 20 -s pulse with dT (Fig. 2). Mitosis (30\%) followed $8 \mathrm{~h}$ after release; a second round of DNA synthesis followed $12 \mathrm{~h}$ after the first.

At different times in the cell cycle samples of medium were taken to test for spontaneously released MGF, and L cells were 